\title{
Validacija prijevoda upitnika SIPP-118 i kratke verzije upitnika PID-5
}

\author{
Tamara Gazdek \\ Srednja škola Donji Miholjac, Donji Miholjac, Hrvatska \\ Katarina Klasić \\ Centar za pružanje usluga u zajednici Osijek "JA kao i TI", Osijek, Hrvatska \\ Andrea Žulj \\ Dječji kreativni centar "DOKKICA", Osijek, Hrvatska \\ Silvija Ručević i Dino Krupić \\ Sveučilište J. J. Strossmayera u Osijeku, Filozofski fakultet, \\ Odsjek za psihologiju, Osijek, Hrvatska
}

\begin{abstract}
Sažetak
Brojna istraživanja upućuju na važnost osobina ličnosti u predikciji različitih oblika rizičnog ponašanja kod adolescenata. U proteklih je nekoliko godina razvijen niz upitnika ličnosti koji su se pokazali uspješnim u predikciji rizičnog ponašanja. Većina tih upitnika nije prevedna na hrvatskom jeziku. Cilj je ovog istraživanja prikazati hrvatske prijevode Upitnika simptoma poremećaja ličnosti (SIPP-118) te kratke verzije Inventara ličnosti za DSM-5 (PID-5). Za procjenu konvergentne valjanosti upitnika PID-5 korištena je Dimenzionalna procjena osobina ličnosti (DiPOL), dok se Samoiskaz rizičnog i delinkventnog ponašanja mladih (SRDP) koristio za ispitivanje prediktivne valjanosti upitnika PID-5 i SIPP-118. Istraživanje je provedeno na 497 učenika gimnazije i strukovnih škola iz Osijeka, Belog Manastira, Đakova i Donjeg Miholjca. Rezultati konfirmatorne faktorske strukture upitnika SIPP-118 nisu potvrdili očekivanu faktorsku strukturu. Petofaktorska struktura upitnika PID-5 pokazala se najboljim modelom, no skale su međusobno suviše povezane što umanjuje divergentnu valjanost upitnika. Rezultati pokazuju kako su osobine ličnosti i indeks funkcioniranja ličnosti umjereno povezani $\mathrm{s}$ tendencijom rizičnog ponašanja. Hijerarhijska regresijska analiza pokazala je da se veći udio varijance u rizičnom ponašanju može objasniti upitnikom DiPOL u odnosu na PID-5. S obzirom na rezultate istraživanja savjetujemo oprez pri korištenju prevedenih upitnika.
\end{abstract}

Ključne riječi: rizično ponašanje, alternativni model poremećaja ličnosti, adolescenti, SIPP118, PID-5

Dino Krupić, Odsjek za psihologiju, Filozofski fakultet Sveučilišta J. J. Strossmayera u Osijeku, Lorenza Jägera 9, 31000 Osijek. E-pošta:dino.krupic@gmail.com 


\section{Uvod}

Delinkventno je ponašanje definirano kao zakonom zabranjeno ponašanje, dok su rizična ponašanja ona kojima se ne krše postojeći pravni propisi, ali često prethode delinkventnom ponašanju, te predstavljaju zdravstveni i psihosocijalni rizik za mlade (Ručević, Ajduković i Šincek, 2009). Dostupni statistički podaci (Stašević i Derk, 2016; Vrselja, Sučić i Franc, 2009; Zloković i Vrcelj, 2010) svjedoče o trendu rasta rizičnog ponašanja adolescenata u Hrvatskoj, što ovu temu čini relevantnom i u znanstvenom i u praktičnom smislu.

Uzroci rizičnih ponašanja adolescenata mogu se pripisati brojnim činiteljima, od obiteljske situacije, utjecaja vršnjaka, individualnih razlika u stavovima i vrijednostima i sl. Međutim, brojna istraživanja ističu značajnu ulogu i osobina ličnosti u predikciji različitih oblika rizičnog i delinkventnog ponašanja kod adolescenata (Asscher i sur., 2011; Gray i Snowden, 2016; Loney, Taylor, Butler i Iacono, 2007; Veltri i sur., 2014). Najveći broj nalaza pokazuje negativnu povezanost savjesnosti i ugodnosti s ulaskom u različita rizična ponašanja (Jolliffe, 2013; Muris, Meesters i Timmermans, 2013). Međutim, pojedine psihopatološke dimenzije povrh dimenzija petofaktorskog modela dodatno objašnjavaju delinkventno ponašanje (Muris i sur., 2013), pri čemu se dimenzije psihopatije - bezosjećajnost i impulzivnost - ističu kao najznačajniji prediktori delinkventnog ponašanja (Asscher i sur., 2011; Ručević, 2010; Walsh, Allen i Kosson, 2007).

Budući da osobine ličnosti predstavljaju relativno trajne karakteristike pojedinca, procjena ličnosti mogla bi biti koristan alat u prevenciji rizičnih oblika ponašanja kod adolescenata. Međutim, psiholozi u Hrvatskoj susreću se $\mathrm{s}$ problemom ograničenog pristupa mjernim instrumentima kojima se koriste psiholozi u inozemstvu iz razloga što se ti mjerni instrumenti prije same primjene trebaju prevesti i validirati na hrvatski jezik, što u konačnici otežava praćenje suvremenih trendova u psihologiji. Jedno od takvih područja jest domena psihopatologije ličnosti u okviru petog izdanja Dijagnostičkog i statističkog priručnika za duševne poremećaje (DSM-5; American Psychiatric Association, 2013). Naime, u III. poglavlju ovog priručnika predložen je alternativni dimenzionalni pristup dijagnosticiranju poremećaja ličnosti prema kojem se naglašava konceptualna razlika oštećenog funkcioniranja ličnosti (kriterij A) od prisutnosti neadaptivnih crta (kriterij B). Međutim, iako je novi DSM-5 objavljen prije šest godina, hrvatski psiholozi još uvijek nemaju adekvatne mjerne instrumente za mjerenje konstrukata u okviru ovoga priručnika.

Stoga, cilj je našega istraživanja adaptirati upitnike ličnosti koji prate promjene u DSM-5 na hrvatski jezik te ispitati njihovu upotrebljivost u predikciji rizičnih ponašanja na uzorku adolescenata. 


\section{Razina funkcioniranja ličnosti}

Kriterij A, u okviru alternativnog modela psihopatologije ličnosti DSM-5, definira temeljne elemente funkcioniranja ličnosti pojedinca koji su zajednički svim poremećajima ličnosti (Bender, Morey i Skodol, 2011; Morey i sur., 2011; Wright, 2011), smetnje u razmišljanju o sebi (domena selfa) i odnosa s drugima (interpersonalna domena) (Berghuis, Kamphuis i Verheul, 2012; Clarkin i Huprich, 2011). Te dvije domene predstavljaju adaptivne kapacitete koje pojedinci razvijaju i usavršavaju tijekom sazrijevanja, a koji su kod osoba s poremećajem ličnosti značajno narušeni (Arnevik, Wilberg, Monsen, Andrea i Karterud, 2009) te se mogu smatrati i indikatorima težine oštećenja funkcioniranja ličnosti (Hopwood i sur., 2011). Promjenjivost poremećaja ličnosti izraženija je za (ne)adaptivne kapacitete (tj. domene funkcioniranja ličnosti u okviru kriterija A) nego za stabilnije crte ličnosti (kriterij B), stoga se sugerira usmjeravanje tretmana upravo na taj funkcionalni dio ličnosti.

Skala za određivanje stupnja oštećenja funkcioniranja ličnosti u sklopu kriterija A DSM-5 naziva se Ljestvica stupnja funkcioniranja ličnosti (engl. Levels of Personality Functioning Scale; LFPS; Morey i sur., 2011), a formirana je na temelju dvaju mjernih instrumenta, (a) Opće procjene poremećaja ličnosti (engl. General Assessment of Personality Disorder; GAPD; Livesley, 2009) te (b) Upitnika simptoma poremećaja ličnosti (engl. Severity Indices of Personality Problems; SIPP118; Verheul i sur., 2008). U okviru ovog istraživanja odlučili smo koristiti upitnik SIPP-118 jer je on novijeg datuma i korišten je u više istraživanja u odnosu na GAPD.

\section{Upitnik simptoma poremećaja ličnosti SIPP-118}

Verheul i sur. (2008) ponudili su svoje viđenje temeljnih elemenata funkcioniranja ličnosti u okviru upitnika SIPP-118 na velikom uzorku kliničke i nekliničke populacije. Upitnik se sastoji od 118 čestica koje čine 16 faceta, koje su prethodno stvorene na temelju konsenzusa istraživača te opsežnog predistraživanja. Tih 16 faceta čini pet faktora višeg reda: a) samokontrola, koja obuhvaća facete kontrole emocija i kontrole nad sobom, b) integracija identiteta, koja uključuje facete samopoštovanja, stabilne slike o sebi, samousmjerenosti, uživanja i uvrhovitosti, c) funkcioniranje u odnosima, koje uključuje facete intimnosti, dugotrajnih odnosa i osjećaja priznanja, d) odgovornost, koja uključuje facete odgovornosti i pouzdanosti, te e) socijalna usuglašenost, koja uključuje facete kontrole agresije, tolerancije frustracije, poštovanja i suradnje.

Pronađena je snažna povezanost poremećaja ličnosti s rezultatima na SIPP-118 (Andrea i sur., 2007), pri čemu se pokazalo kako ovaj instrument uspješno razlikuje pojedince $\mathrm{s}$ dijagnozom poremećajem ličnosti u odnosu na neklinički uzorak (Verheul i sur., 2008). Test-retest-pouzdanost u kratkom vremenskom razdoblju na 
studentskoj populaciji bila je vrlo visoka (od .87 za Socijalnu usuglašenost do .95 za Samokontrolu), pokazujući kako je SIPP-118 relativno neosjetljiv na kratkoročne promjene stanja. No, u istom su se istraživanju rezultati kliničke populacije nakon dvogodišnjeg tretmana poboljšali, upućujući na osjetljivost SIPP-118 na srednjoročne i na dugoročne adaptacijske promjene (Verheul i sur., 2008). Iako je razvijen prvenstveno u istraživačke svrhe, njegove psihometrijske karakteristike čine ga potencijalnim mjernim instrumentom za provjeru ishoda tretmana te $u$ dijagnostičke svrhe, što je još uvijek predmet istraživanja (Rossi, Debast i van Alphen, 2016).

Psihometrijske karakteristike SIPP-118 ispitivale su se u nekoliko istraživanja. Prvo od takvih bilo je istraživanje Arnevik i sur. (2009) na norveškom uzorku od 114 sudionika s dijagnosticiranim poremećajem ličnosti. Rezultati su pokazali dobre psihometrijske pokazatelje na razini faceta, a rezultati norveškog uzorka osoba s poremećajem ličnosti usporedivi su s nizozemskim uzorkom (Verheul i sur., 2008). Konkretno, rezultati osoba s poremećajem ličnosti bili su značajno niži od rezultata opće populacije na svim facetama, osim faceti Poštovanja. Nadalje, Berghuis i sur. (2012) proveli su istraživanje u kojemu su koristili SIPP-118 zajedno s GAPD-om, te su na temelju njih ekstrahirali samo tri faktora koja su predstavljala temeljne elemente funkcioniranja ličnosti. S obzirom na sadržaj nazvali su ih funkcioniranje na domeni selfa i identiteta, prosocijalno funkcioniranje i poteškoće u odnosima. S druge strane, Bastiaansen, De Fruyt, Rossi, Schotte i Hofmans (2013) u svom su istraživanju pronašli četiri faktora višeg reda, koje su nazvali samokontrola, integracija identiteta, funkcioniranje u odnosima i odgovornost. Iako domene nose iste nazive kao i domene u istraživanju Verheula i sur. (2008), važno je napomenuti kako se one samo djelomično preklapaju, a facete koje su u izvornom istraživanju činile domenu Socijalne usuglašenosti sada se nalaze unutar ove četiri dobivene domene.

S obzirom na to da se faktorska struktura višeg reda u različitim istraživanjima pokazala manje konzistentnom, u okviru ovog istraživanja testirat će se više modela kako bi se utvrdila faktorska struktura upitnika SIPP-118 na hrvatskom uzorku adolescenata.

\section{Osnovne dimenzije psihopatologije ličnosti prema PID-5}

Drugi je kriterij za dijagnozu poremećaja ličnosti prisutnost patoloških crta ličnosti. Inventar ličnosti za DSM-V (engl. Personality Inventory for DSM-5; PID5) predstavlja mjeru osnovnih dimenzija psihopatologije ličnosti, koju je sastavio radni tim stručnjaka koji su radili na petom izdanju Dijagnostičkog i statističkog priručnika za mentalne poremećaje.

Krueger, Derringer, Markon, Watson i Skodol (2012) kreirali su inicijalni set čestica kojima se nastojalo zahvatiti 37 crta ličnosti koje su smatrane relevantnim za ispitivanje psihopatologije ličnosti. Pošli su od pretpostavke da te crte predstavljaju 
faktore nižeg reda za četiri glavne domene maladaptivne varijacije ličnosti koju su predložili Widiger i Simonsen (2005). Od početnih 37, zadržano je 25 dimenzija hijerarhijski organiziranih u pet glavnih psihopatoloških osobina ličnosti koje su nazvali: negativni afekt, otuđenost, psihoticizam, antagonizam i dezinhibicija (Quilty, Ayearst, Chmielewski i Bagby, 2013). Negativni afekt karakteriziraju učestala i intenzivna doživljavanja visokih razina velikog raspona negativnih emocija (anksioznost, depresija, krivnja/sram, briga, ljutnja) i njihovih ponašajnih (npr. samoranjavanje) i interpersonalnih (npr. ovisnost) manifestacija. Otuđenost predstavlja izbjegavanje socioemocionalnog iskustva, uključujući povlačenje od interpersonalnih interakcija (od svakodnevnih interakcija s prijateljima do intimnih odnosa) te ograničeno afektivno iskustvo i ekspresiju, osobito ograničen kapacitet ugode. Antagonizam uključuje sklonost natjecanja s drugima, uključujući pretjerani osjećaj važnosti i istodobno očekivanje posebnog tretmana, bešćutnost prema drugima, izostanak razumijevanja potreba i osjećaja drugih ljudi te sklonost iskorištavanja drugih radi vlastite koristi. Dezinhibicija je usmjerenost prema neposrednom zadovoljenju koja vodi $\mathrm{k}$ impulzivnom ponašanju koje je potaknuto trenutnim mislima, osjećajima i vanjskim podražajima bez obzira na prijašnje ili buduće posljedice. Psihoticizam predstavlja doživljavanje širokog spektra kulturalno inkongruentnoga, čudnoga, ekscentričnog ili neobičnog ponašanja i razmišljanja (Krueger i Markon, 2014).

Puna forma tog inventara ima 220 čestica i u brojnim se istraživanjima pokazao valjanim i pouzdanim (Hopwood i Sellbom, 2013). Također, razvijene su i dvije kratke forme koje se sastoje od 100 (PID5-100; Maples i sur., 2015) i 25 čestica (PID5-25; Krueger, Derringer, Markon, Watson i Skodol, 2013) podijeljenih u pet faktora. U okviru ovog istraživanja očekuje se da će se konfirmatornom faktorskom analizom (CFA) potvrditi petofaktorska struktura (negativni afektivitet, otuđenost, antagonizam, dezinhibicija i psihoticizam) prijevoda upitnika PID-a kratke forme od 25 čestica.

U sklopu ovog rada prikazat će se validacija prijevoda upitnika SIPP-118 na hrvatski jezik, upitnika namijenjenog ispitivanju razine funkcioniranja ličnosti, te kratke verzije upitnika PID5-25 namijenjenog mjerenju temeljnih dimenzija psihopatologije. Zatim će se ispitati prediktivna valjanost navedenih upitnika $\mathrm{s}$ obzirom na rizična ponašanja adolescenata.

\section{Sudionici}

\section{Metoda}

U istraživanju je sudjelovalo 449 učenika (149 mladića) srednjih škola u Osječko-baranjskoj županiji. Istraživanje je provedeno u strukovnim školama $(N=$ 361) te gimnazijama $(N=88)$. Podaci su prikupljani od svibnja do lipnja 2016. godine. Raspon dobi sudionika kretao se od 14 do 20 godina, dok je prosječna dob 
iznosila $M=16.55$ ( $S D=1.14$ ). Svi su sudionici bili informirani o svrsi istraživanja te su dali pismenu suglasnost za sudjelovanje u istraživanju. Etičko povjerenstvo Odsjeka za psihologiju na Filozofskom fakultetu u Osijeku dalo je odobrenje za provođenje istraživanja.

\section{Instrumenti}

Upitnik simptoma poremećaja ličnosti (engl. Severity Indices of Personality Problems 118; SIPP-118; Verheul i sur., 2008) upitnik je samoiskaza namijenjen mjerenju težine patologije ličnosti pomoću temeljnih elemenata (ne)adaptivnog funkcioniranja ličnosti. Uputom se od sudionika traži da na skali Likertova tipa procijene u kojem se stupnju tvrdnje odnose na njih u posljednja tri mjeseca $(1-u$ potpunosti se ne slažem do 4 - u potpunosti se slažem). Upitnik sadrži 118 čestica kojima se mjeri 16 faceta: kontrola emocija, kontrola nad sobom, samopoštovanje, stabilna slika o sebi, samousmjerenost, uživanje, svrhovitost, odgovornost, pouzdanost, intimnost, dugotrajni odnosi, osjećaj priznanja, kontrola agresije, tolerancija frustracije, suradnja i poštovanje. U izvornom istraživanju Verheula i sur. (2008) te istraživanju na adolescentima (Feenstra, Hutsebaut, Verheul i Busschbach, 2011) 16 faceta čini pet faktora višeg reda - samokontrola, integracija identiteta, funkcioniranje u odnosima, odgovornost i socijalna usuglašenost. Viši rezultati na dimenzijama ovog upitnika upućuju na adaptivno funkcioniranje. Koeficijenti internalne konzistencije iskazani Cronbachovim alfa koeficijentom za skale unutar ovog upitnika na kliničkom uzorku odraslih osoba kreću se od .69 do .84 (Verheul i sur., 2008), dok na adolescentskom uzorku od .69 do .82, s tim da skale kontrole nad sobom (.62) i poštovanja (.59) upućuju na nešto nižu pouzdanost (Feenstra i sur., 2011).

DSM-5 Inventar ličnosti - kratka forma 25 (engl. The Personality Inventory for DSM-5-Brief form; PID-5; Krueger i sur., 2013) upitnik je koji se sastoji od 25 čestica podijeljenih u pet faktora: negativni afekt (,, Lako se uznemirim, čak i kada su u pitanju sitnice."), otuđenost (,Ne volim se previše zbližavati s ljudima."), antagonizam (,, Nije me briga ako povrijedim osjećaje drugih ljudi."), dezinhibicija (,Iako znam da mogu bolje, ne mogu prestati donositi brzoplete odluke.") i psihoticizam (, Viđao/la sam stvari koje nisu zaista postojale."). Od sudionika se traži da na skali Likertova tipa od 0 (Uopće se ne odnosi na mene.) do 3 (U potpunosti se odnosi na mene") procijene koliko se svaka tvrdnja odnosi na njih, a rezultat se na svakoj skali formira zbrajanjem rezultata svih čestica koje im pripadaju. Pouzdanost skala dezinhibicije, negativnog afekta i otuđenosti mjerene Cronbachovim alfa koeficijentom niže su od granične vrijednosti od .70 (Fossati, Somma, Borroni, Markon i Krueger, 2015).

Oba upitnika, SIPP-118 i PID-5, prevedeni su postupkom povratnoga prijevoda na jezik izvornika (engl. back-translation), u čemu su sudjelovali svi autori ovog rada. Drugim riječima, upitnici su s engleskog jezika prevedeni na hrvatski, zatim su 
ih nezavisni prevoditelji s hrvatskog jezika preveli na engleski. Konačna verzija na engleskom jeziku uspoređena je s originalnom verzijom upitnika na engleskom te su se po potrebi pojedine čestice korigirale i usklađivale.

Dimenzionalna procjena osobina ličnosti (DiPOL) (Krupić i Ručević, 2015). Upitnik se sastoji od 62 čestice, a namijenjen je mjerenju osobina ličnosti adolescenata prema DSM-5, koji čini pet glavnih ljestvica: negativna emocionalnost (,, Strah me je da će me drugi gledati manje vrijednim/nom kada me malo bolje upoznaju."), otuđenost $^{1}$ (,Ne osjećam tugu nad tuđim teškim sudbinama."), kompulzivnost (,Često radim prekovremeno kako bih bio/la maksimalno uspješan/na. “), psihoticizam (,,Cijelo vrijeme postoji netko od gore ili nešto što me pazi i gleda svaki moj pokret. ") i antagonizam (,Donosim brze odluke bez pretjeranog razmišljanja. "), uz dodatne ljestvice grandioznosti (,,Jednog dana kada realiziram svoje ideje svijet će pamtiti moje ime.") i traženja pozornosti (,Ponekad namjerno pretjerano reagiram u društvu kako bi me drugi primijetili."). Sudionici za svaku tvrdnju procjenjuju u kojem se stupnju odnosi na njih na skali Likertova tipa od 1 (Uopće se ne odnosi na mene.) do 5 (U potpunosti se odnosi na mene.). Rezultat na svakoj skali formira se zbrajanjem rezultata svih čestica koje im pripadaju. Koeficijenti pouzdanosti za skale upitnika u ovom istraživanju kreću se od .74 do .86.

Samoiskaz rizičnog i delinkventnog ponašanja mladih (SRDP; Ručević i sur., 2009). Sastoji se od 42 čestice koje čine sedam faktora (prekršajna i lakša delinkventna ponašanja, nepoželjna normativna ponašanja, rizična spolna ponašanja, korištenje ili zlouporaba psihoaktivnih tvari, nasilničko ponašanje u bliskim odnosima, teža krađa, provale i razbojništvo i suicidalna i autoagresivna ponašanja). Svakoj čestici pripada i određeni indeks težine kojim se mjeri ozbiljnost ponašanja. Ukupni rezultat formira se kao zbroj umnožaka čestine pojedinih ponašanja i pripadajućih indeksa težine na svim česticama unutar pojedinih ljestvica. Od sudionika se traži da za svaku izjavu zaokruži odgovor koliko se puta ponašao na određeni način, a ponuđeni su odgovori: nikad, 1 - 2 puta, 3 - 5 puta, 6 i više puta. Viši rezultat upućuje na izraženije rizično ponašanje.

\section{Postupak}

Istraživanje je provedeno u školama u skupinama po dvadesetak sudionika tijekom sata razredne nastave. Prije početka svim je sudionicima pročitana zajednička uputa kojom ih se upoznalo s predmetom istraživanja pri čemu je naglašena anonimnost i važnost iskrenog odgovaranja, kao i mogućnost odustajanja od istraživanja. Nakon toga, učenicima su podijeljene suglasnosti koje su potpisali ako su pristali sudjelovati u istraživanju. Rješavanje upitnika trajalo je do 45 minuta.

\footnotetext{
1 Naziv skale otuđenost $\mathrm{u}$ validacijskom se radu upitnika DiPOL navodi pod nazivom emocionalna isključenost (Krupić i Ručević, 2015). Razlog izmjeni naziva skale jest usklađivanje terminologije s upitnikom PID-5 s obzirom na to da su te dvije skale namijenjene mjerenju istih konstrukata.
} 


\section{Rezultati}

Konstruktna valjanost upitnika SIPP-118 i PID-5 provjerena je konfirmatornom faktorskom analizom metodom procjene najveće vjerojatnosti (engl. maximum likelihood estimation) pomoću programa IBM SPSS Amos 7. Kao pokazatelji pristajanja modela promatrali su se: a) hi-kvadrat $\left(\chi^{2}\right)$ i njegov omjer u odnosu na broj stupnjeva slobode $\left(\chi^{2} / s s\right)$ (Bentler, 2007), pri čemu se vrijednost relativnog hikvadrata između 2 i 5 najčešće prihvaća kao model dobrog pristajanja (Marsh i Hocevar, 1985); b) standardizirana prosječna kvadratna kovarijanca reziduala (engl. the root mean squared error of approximation; RMSEA; Steiger, 2000), pri čemu se vrijednosti $<.05$ uzimaju kao pokazatelji dobrog pristajanja modela, .05 - .08 kao umjerenog, .08 - . 10 kao graničnog, dok vrijednosti > .10 upućuju na loše pristajanje empirijskih podataka testiranom modelu (Browne i Cudeck, 1993; Hu i Bentler, 1999); i c) komparativni indeks pristajanja (engl. the comparative fit index; CFI), gdje vrijednosti između .90 i .95 upućuju na prihvatljivo pristajanje, a vrijednosti iznad .95 na dobro ili izvrsno pristajanje modela (Hu i Bentler, 1999). Budući da će se $\mathrm{u}$ radu prikazati i usporedba pristajanja različitih modela istim podacima iz upitnika, za svaki od njih bit će prikazana i vrijednost Akaike informacijskog kriterija (AIC; Akaike, 1987). U oba slučaja varijance latentnih varijabli nisu bile fiksirane, tj. ti su se parametri slobodno procjenjivali.

\section{Faktorska struktura prijevoda SIPP-118}

Cronbachov $\alpha$ koeficijent unutarnje konzistencije svih 16 faceta kreće se od .63 do .86 , a koeficijenti su usporedivi s koeficijentima pouzdanosti na adolescentskom nekliničkom uzorku (Feenstra i sur., 2011) te kliničkom uzorku odrasle populacije iz izvornog istraživanja (Verheul i sur., 2008). Jedino je pouzdanost facete intimnost ( $\alpha$ $=.63$ ) nešto niža u usporedbi s navedenim istraživanjima.

Za provjeru petofaktorske strukture SIPP-118 modela Verheula i sur. (2008), a kasnije i Feenstre i sur. (2011) na adolescentskom uzorku, provedena je konfirmatorna faktorska analiza nad facetama (Slika 1.). Indikatori pogodnosti modela upućuju na loše pristajanje empirijskih podataka tako postavljenoga teorijskog modela (Tablica 1.), zbog čega smo ispitali alternativne modele. Alternativna faktorska struktura SIPP118, koju su predložili Bastiaansen i sur. (2013) (vidjeti opis u uvodu), pokazala se još lošijom u odnosu na prethodni model (Tablica 1.). Još u DSM-IV simptomi ozbiljnosti patologije psihološkoga, socijalnog i radnog funkcioniranja mjerili su se na kontinuumu od mentalnog zdravlja do duševne bolesti, instrumentom Opće procjene funkcioniranja (Global Assessment of Functioning (GAF); American Psychiatric Association, 1994). Po uzoru na taj instrument konfirmatornom je faktorskom analizom provjerena i hijerarhijska struktura prethodno navedenih modela, pri čemu bi pet, odnosno četiri glavne domene formirale jedan faktor višeg reda, koji bi predstavljao ukupni indeks funkcioniranja osobe. Međutim, ni jedan model nije se pokazao adekvatnim (Tablica 1.). 


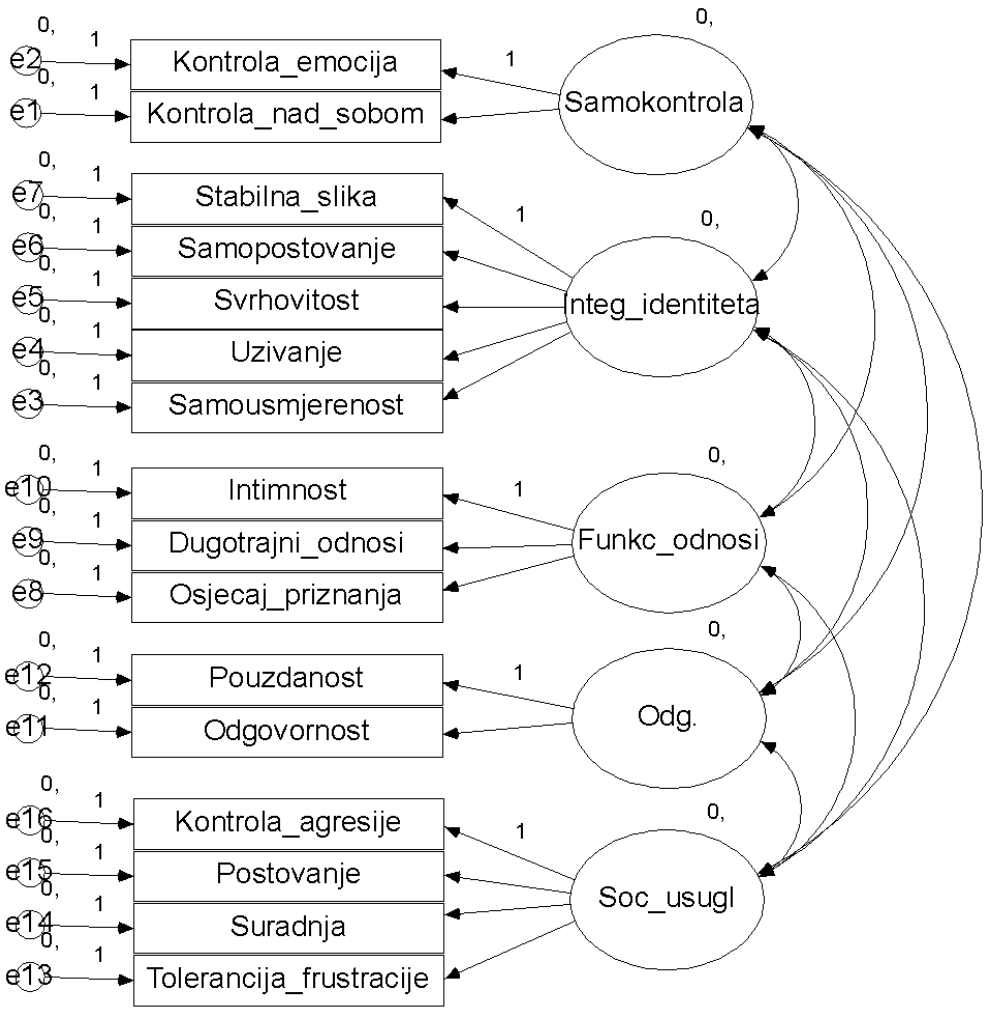

Slika 1. Model SIPP-118 prema Verheulu i sur. (2008).

Napomena: Stabilna_slika = stabilna slika o sebi, Integ_identiteta = sntegracija identiteta, Funkc_odnosi $=$ sunkcioniranje $\mathrm{u}$ odnosima, Odg. $=$ odgovornost, Soc_usugl $=$ socijalna usuglašenost.

Tablica 1.

Indeksi pogodnosti za upitnik SIPP-118

\begin{tabular}{lcccccc}
\hline Modeli & $\chi^{2}(s s)$ & $\chi^{2} / s s$ & CFI & RMSEA & AIC \\
\hline $\begin{array}{l}\text { Model s pet domena (Feenstra i } \\
\text { sur., 2011; Verheul i sur., 2008) }\end{array}$ & $737.23^{* *}$ & (94) & 7.84 & .883 & .117 & 853.23 \\
\hline $\begin{array}{l}\text { Model s četiri domene } \\
\text { (Bastiaansen i sur., 2013) }\end{array}$ & $769.68^{* *}$ & $(98)$ & 7.85 & .878 & .117 & 877.68 \\
\hline $\begin{array}{l}\text { Hijerarhijski model, pet domena } \\
\text { s jednim faktorom višeg reda } \\
\text { (Verheul i sur., 2008) }\end{array}$ & $865.63^{* *}$ & $(99)$ & 8.74 & .860 & .125 & 971.63 \\
\hline $\begin{array}{l}\text { Hijerarhijski model, četiri domene } \\
\text { s jednim faktorom višeg reda } \\
\text { (Bastiaansen i sur., 2013) }\end{array}$ & $810.44^{* *}(100)$ & 8.10 & .871 & .120 & 914.44 \\
\hline$* * * .01$ & & & & & & \\
\hline$p<.01$
\end{tabular}


Stoga, sljedeći je korak bilo traženje modela eksploratornom faktorskom analizom. Vrijednost Kaiser-Meyer-Olkinova testa iznosila je .93. Prilikom provjere faktorske strukture kao metoda ekstrakcije korištena je metoda glavnih osi uz kosokutnu rotaciju. Kaiserov kriterij (karakteristični korijen veći od 1) sugerirao je tri faktora koja bi objasnila $61.81 \%$ varijance. Cattellov Scree Plot i paralelna analiza sugeriraju zadržavanje dvaju faktora koji međusobno koreliraju $r=.65$ (Tablica 4.), a zajedno objašnjavaju $57.51 \%$ varijance. Karakteristični je korijen trećeg (nezadržanog) faktora iznosio 1.006. S obzirom na sadržaj skala koje su imale najveće zasićenje na pojedinom faktoru, dobiveni su faktori nazvani domena selfa i interpersonalna domena. Domenu self čini deset skala, dok interpersonalnu dimenziju čini šest skala prikazanih u Tablici 2. Nazivi su usklađeni s hrvatskim prijevodom ljestvice stupnja funkcioniranja ličnosti u DSM-5 (Američka psihijatrijska udruga, 2014).

Tablica 2.

Matrica obrasca i prikaz deskriptivnih podataka faceta SIPP-118

\begin{tabular}{lccccccc}
\hline Faceta & Self & Interpersonalno & $h^{2}$ & $M$ & $S D$ & $\alpha$ & $\begin{array}{c}\text { Broj } \\
\text { čestica }\end{array}$ \\
\hline kontrola nad sobom & $\mathbf{. 9 4}$ & -.22 & .70 & 18.00 & 4.368 & .73 & 7 \\
kontrola emocija & $\mathbf{. 8 3}$ & -.06 & .64 & 20.57 & 4.575 & .78 & 7 \\
tolerancija frustracije & $\mathbf{. 7 8}$ & .06 & .67 & 22.20 & 4.489 & .71 & 8 \\
samousmjerenost & $\mathbf{. 7 2}$ & .09 & .61 & 19.55 & 4.046 & .67 & 7 \\
stabilna slika o sebi & $\mathbf{. 7 1}$ & .22 & .73 & 20.34 & 4.612 & .78 & 7 \\
odgovornost & $\mathbf{. 6 8}$ & -.05 & .43 & 18.35 & 4.451 & .74 & 7 \\
pouzdanost & $\mathbf{. 6 5}$ & .08 & .49 & 22.89 & 4.340 & .72 & 8 \\
kontrola agresije & $\mathbf{. 6 2}$ & .11 & .48 & 24.35 & 5.862 & .86 & 8 \\
svrhovitost & $\mathbf{. 5 6}$ & .30 & .59 & 21.12 & 4.100 & .70 & 7 \\
samopoštovanje & $\mathbf{. 4 9}$ & .37 & .58 & 24.60 & 5.006 & .78 & 8 \\
dugotrajni odnosi & .07 & $\mathbf{. 8 3}$ & .76 & 22.03 & 4.145 & .70 & 7 \\
suradnja & .11 & $\mathbf{. 7 2}$ & .62 & 24.44 & 4.634 & .78 & 8 \\
intimnost & -.14 & $\mathbf{. 6 9}$ & .38 & 18.84 & 3.889 & .63 & 7 \\
osjećaj priznanja & .18 & $\mathbf{. 6 2}$ & .55 & 21.89 & 4.580 & .69 & 8 \\
uživanje & .37 & $\mathbf{. 4 9}$ & .59 & 21.45 & 4.108 & .72 & 7 \\
poštovanje & .28 & $\mathbf{. 4 2}$ & .39 & 22.75 & 3.549 & .67 & 7 \\
\hline karakteristični korijeni & 7.29 & 5.63 & & & & & \\
\hline
\end{tabular}

Napomena: Koeficijenti >.30 prikazani su podebljano i zadržani su za navedeni faktor. $h^{2}=$ komunalitet.

\section{Faktorska struktura prijevoda kratke verzije PID-5}

Cronbachov $\alpha$ koeficijent pouzdanosti kreće se od .69 do .78 (Tablica 3.), te je blago veći u odnosu na one dobivene na talijanskom adolescentskom nekliničkom uzorku (Fossati i sur., 2015). 
Tablica 3.

Osnovni deskriptivni podaci upitnika PID-5

\begin{tabular}{lccc}
\hline & $\alpha$ & $M$ & $S D$ \\
\hline negativni afektivitet & .73 & 6.91 & 3.778 \\
otuđenost & .69 & 4.32 & 3.202 \\
antagonizam & .78 & 3.12 & 3.285 \\
dezinhibicija & .76 & 5.14 & 3.503 \\
psihoticizam & .77 & 5.86 & 3.883 \\
\hline
\end{tabular}

Za provjeru je petofaktorske strukture PID-5 na adolescentskom uzorku provedena konfirmatorna faktorska analiza, a navedeni je model prikazan na Slici 2. Empirijski podaci odgovaraju teorijskom modelu; omjer $\chi^{2}$ i stupnjeva slobode iznosio je $2.48\left(\chi^{2}=643.6\right.$, $\left.s s=260\right)$; CFI $=.90$, te RMSEA $=.06$. Korelacija je između faktora otuđenosti i antagonizma visoka $(r=.75)$, kao i korelacije između otuđenosti i dezinhibicije $(r=.73)$ te otuđenosti i psihoticizma $(r=.71)$. Naravno, iznosi korelacija među skalama nešto su niži (od .16 do .53) kada se računaju Pearsonovi koeficijenti korelacije s kompozitnim varijablama (Tablica 4.), što je viša procjena u odnosu na interkorelacije među skalama upitnika DiPOL (raspon korelacija iznosi od .00 do .34).

S obzirom na to da su upitnici PID-5 i DiPOL kreirani s namjenom mjerenja istih konstrukata, oni nisu dovoljno povezani. Najviša je konvergentna valjanost ustanovljena za PID-5 negativni afektivitet u odnosu na negativnu emocionalnost DiPOL-a $(r=.48, p<.001)$, što nije dovoljno kada je u pitanju konvergentna valjanost. S druge strane, u nekoliko je slučajeva narušena divergentna valjanost poput, npr. korelacije između antagonizma DiPOL-a i psihoticizma PID-5 ( $r=.33$, $p<.01)$.

Zaključno, potvrđena je petofaktorska struktura kratke verzije upitnika PID-5, no skale su suviše međusobno povezane, dok sa skalama DiPOL postižu niske i neočekivane korelacije, što govori u prilog nedovoljnoj konvergentnoj i divergentnoj valjanosti.

\section{Povezanost razine funkcioniranja i osobina psihopatologije ličnosti sa sklonosti rizičnog ponašanja}

Koeficijenti unutarnje konzistencije (Cronbachov alfa) za sve se skale SRDP-a kreću od .71 do .89 , a pouzdanost cijelog upitnika iznosi .91. Sve skale PID-5 (osim negativnog afekta), DiPOL-ove skale antagonizma i grandioznosti umjereno pozitivno koreliraju s rizičnim ponašanjem, a DiPOL-ova skala kompulzivnost (naspram dezinhibicije) umjereno negativno. 


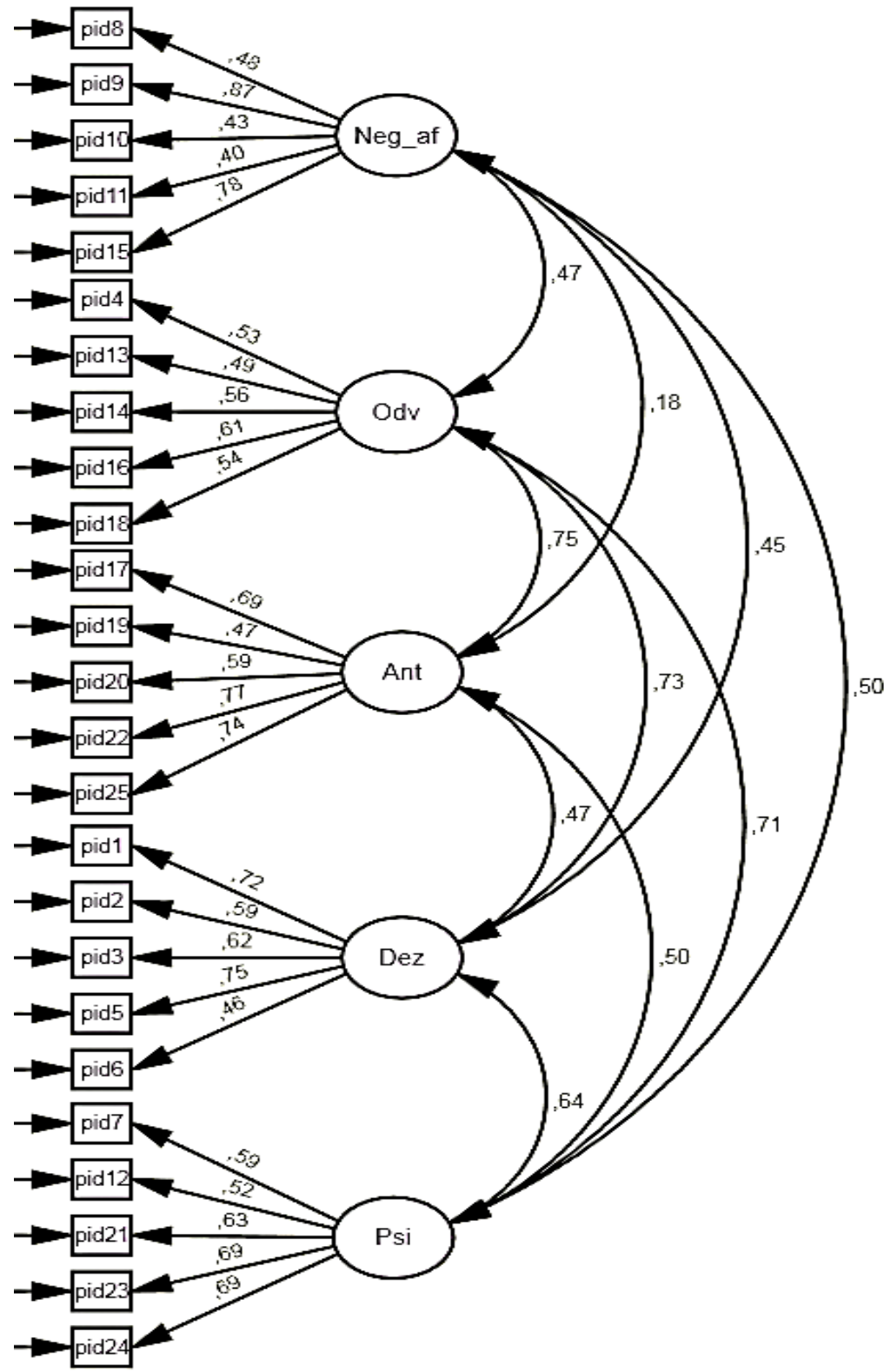

Slika 2. Model PID-5.

Napomena: Neg_af = negativni afekt, Odv = otuđenost, Ant $=$ antagonizam, Dez $=$ dezinhibicija, Psi $=$ psihoticizam. 
Gazdek, T., Klasić, K., Žulj, A., Ručević, S., Krupić, D.:

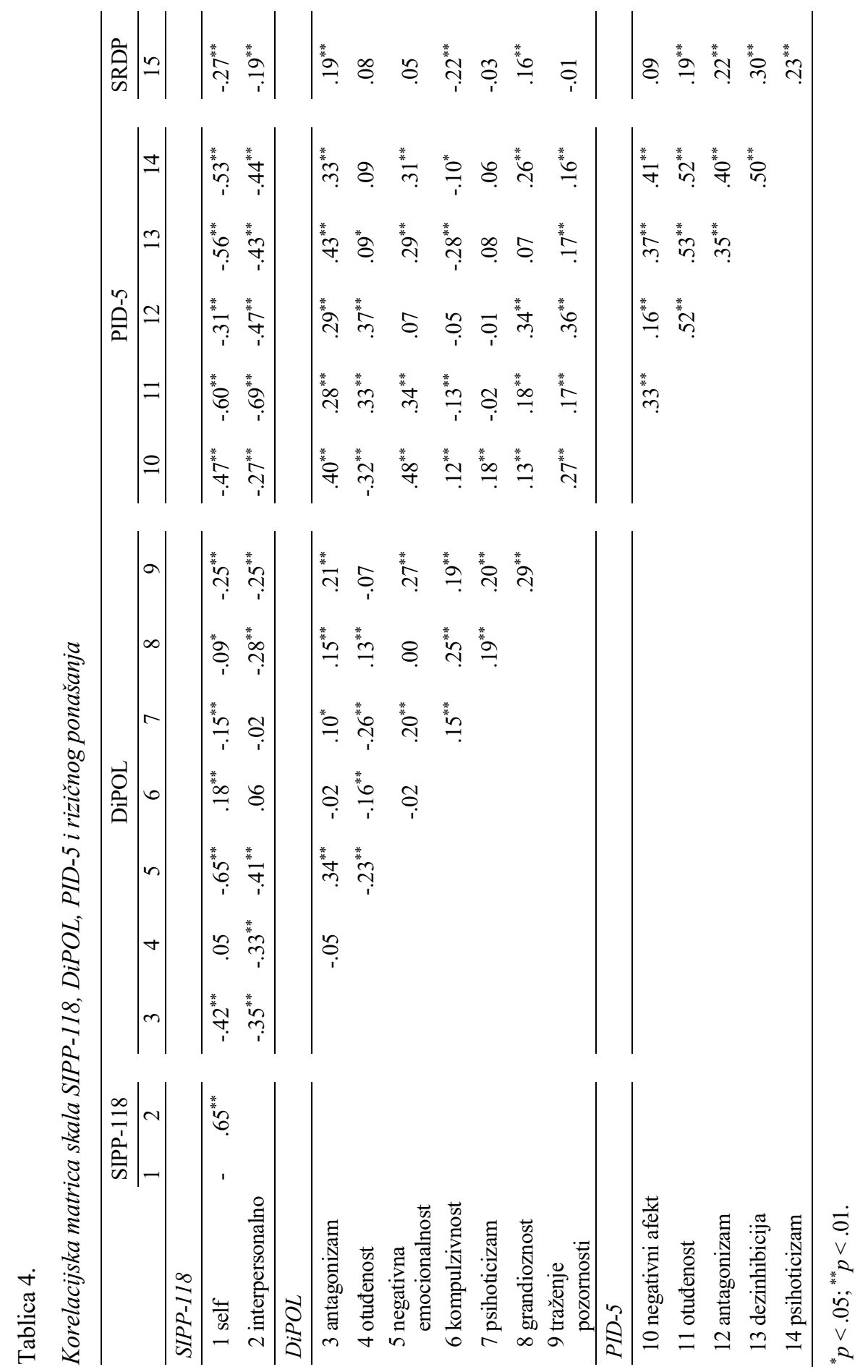


Kako bi se ispitala uloga osobina ličnosti u pojavnosti rizičnog ponašanja, provedene su dvije zasebne hijerarhijske regresijske analize kako bi se ispitale razlike u prediktivnoj valjanosti između upitnika DiPOL i PID-5. Ukupni rezultati SRDP-a mladih korišteni su kao kriterijska varijabla. Prvi korak u modelu predstavljaju varijable dob i spol, u drugom su koraku uvrštene dvije skale upitnika SIPP-118, dok su u trećem uvrštene skale DiPOL-a, odnosno PID-5. Provjerom pokazatelja multikolinearnosti i pokazatelja nezavisnosti reziduala utvrđeno je kako su zadovoljeni uvjeti za regresijske analize. Rezultati hijerarhijske regresijske analize prikazani su u Tablicama 5. i 6.

Prema Tablici 5. vidljivo je kako se broj rizičnih ponašanja povećava u funkciji dobi, te je nešto veći kod mladića u odnosu na djevojke. Razina osobnog funkcioniranja u drugom koraku modela jednaka je u obje tablice (Tablice 5. i 6.). Kao što je vidljivo, domena SIPP-118 selfa je značajan prediktor i rizičnog ponašanja. Nakon uključivanja upitnika PID-5 u trećem koraku modela (Tablica 5.) objašnjeno je dodatnih 4.9 \% varijance SRDP-a. Skala selfa ostaje značajni prediktor rizičnog ponašanja, dok se samo skala dezinhibicije pokazala značajnim prediktorom. Kompozitna skala SIPP-118 self ostaje značajan prediktor rizičnog ponašanja i nakon dodavanja upitnika DiPOL, koji u trećem koraku modela objašnjava dodatnih $8.1 \%$ varijance SRDP-a (Tablica 6.), pri čemu skale antagonizma, grandioznosti i dezinhibicije (rekodirana skala kompulzivnosti) pozitivno predviđaju rizična ponašanja.

Tablica 5.

Predikcija rizičnog ponašanja s upitnicima SIPP-118 i PID-5

\begin{tabular}{llc}
\hline Korak & & Rizično ponašanje \\
\hline \multirow{2}{*}{1} & spol & $-.157^{* *}$ \\
& dob & $.173^{* *}$ \\
\cline { 2 - 3 } & $\Delta R^{2}$ & .055 \\
& $F(2,439)$ & $12.805^{* *}$ \\
\hline \multirow{4}{*}{2} & spol & $-.173^{* *}$ \\
& dob & $.207^{* *}$ \\
& SIPP-118 self & $-.301^{* *}$ \\
& SIPP-118 interpersonalno & .008 \\
\cline { 2 - 3 } & $\Delta R^{2}$ & .086 \\
& $F(2,437)$ & $17.926^{* *}$ \\
\hline \multirow{4}{*}{3} & spol & $-.138^{* *}$ \\
& dob & $.219^{* *}$ \\
& SIPP-118 self & $-.217^{* *}$ \\
& SIPP-118 interpersonalno & .051 \\
& PID negativni afekt & -.088 \\
& PID otuđenost & -.063 \\
& PID antagonizam & .076 \\
& PID disinhibicija & $.207^{* *}$ \\
& PID psihoticizam & .106 \\
\cline { 2 - 3 }$\Delta R^{2}$ & .049 \\
& $F(7,430)$ & $11.280^{* *}$ \\
\hline
\end{tabular}

Napomena: ${ }^{*} p<.05 ;{ }^{* *} p<.01$; spol predstavlja dihotomnu varijablu pri čemu se negativan predznak betapondera interpretira kao veći rezultat kod muških sudionika u odnosu na ženske. 
Tablica 6.

Predikcija rizičnog ponašanja s upitnicima SIPP-118 i DiPOL

\begin{tabular}{llc}
\hline Korak & & Rizično ponašanje \\
\hline 1 & spol & $-.157^{* *}$ \\
& dob & $.173^{* *}$ \\
\cline { 2 - 3 } & $\Delta R^{2}$ & .055 \\
& $F(2,439)$ & $12.805^{* *}$ \\
\hline \multirow{4}{*}{2} & spol & $-.173^{* *}$ \\
& dob & $.207^{* *}$ \\
& SIPP-118 self & $-.301^{* *}$ \\
& SIPP-118 interpersonalno & .008 \\
\cline { 2 - 3 } & $\Delta R^{2}$ & .086 \\
& $F(2,437)$ & $17.926^{* *}$ \\
\hline \multirow{4}{*}{3} & spol & $-.137^{* *}$ \\
dob & $.212^{* *}$ \\
SIPP-118 self & $-.311^{* *}$ \\
SIPP-118 interpersonalno & .061 \\
DiPOL antagonizam & $.147^{* *}$ \\
DiPOL otuđenost & .014 \\
DiPOL negativna emocionalnost & -.099 \\
DiPOL kompulzivnost & $-.178^{* *}$ \\
DiPOL psihoticizam & -.021 \\
DiPOL grandioznost & $.181^{* *}$ \\
DiPOL traženje pozornosti & -.098 \\
\cline { 2 - 2 } & $\Delta R^{2}$ & .081 \\
$F(7,430)$ & $11.170^{* *}$
\end{tabular}

Napomena: ${ }^{*} p<.05 ;{ }^{* *} p<.01$; spol predstavlja dihotomnu varijablu pri čemu se negativan predznak betapondera interpretira kao veći rezultat kod muških sudionika u odnosu na ženske.

\section{Rasprava}

Cilj je ovog istraživanja bio prikazati validaciju prijevoda upitnika SIPP-118 i PID-5 te ispitati ulogu psihopatologije ličnosti prema alternativnom modelu DSM-5 $\mathrm{u}$ predviđanju rizičnog ponašanja na uzorku učenika srednjih škola s područja Osječko-baranjske županije.

Petofaktorska struktura upitnika SIPP-118 nije se potvrdila, što je u skladu s ranije provedenim istraživanjima u kojima je dobivena različita faktorska struktura (Bastiaansen i sur., 2013; Berghuis i sur., 2012; Feenstra i sur., 2011; Morey i sur., 2011). No, čini se da ovaj problem nije vezan samo uz ovaj upitnik, jer i drugi upitnici funkcioniranja ličnosti, poput Skala razine funkcioniranja ličnosti (engl. Level of Personality Functioning Scale; Morey, 2017) i Generalne procjene poremećaja ličnosti (engl. General Assessment of Personality Disorder, GAPD, Livesley, 2009) također postižu visoku međusobnu povezanost indikatora funkcioniranja iz domena selfa i interpersonalnog funkcioniranja. Dvije su moguće interpretacije. Prvo se 
objašnjenje odnosi na samu prirodu konstrukta, što bi podrazumijevalo kako intrapsihičke smetnje dovode do problema u odnosu s drugima, ali i obrnuto. Drugo se moguće objašnjenje odnosi na nedovoljno preciznu operacionalizaciju različitih aspekata funkcioniranja ličnosti - konstrukta koji se tek nedavno počeo aktivnije istraživati.

Kada govorimo o adaptaciji SIPP-118 na našem jeziku, smatramo da su rezultati faktorske strukture prikazane u ovom radu najadekvatnije rješenje, jer ta dva faktora jasno opisuju koje facete pripadaju osnovnim kategorijama procjene funkcioniranja ličnosti prema alternativnom modelu psihopatologije ličnosti prema DSM-5 domeni selfa $\mathrm{i}$ odnosa $\mathrm{s}$ drugima. Bez obzira na činjenicu što nismo potvrdili originalnu faktorsku strukturu upitnika, smatramo da zbog svoje sveobuhvatnosti ovaj upitnik može biti primjenjiv ako bi se podaci ispitanika analizirali na razini faceta, a ne na razini generalnih faktora. $U$ istraživačke bi se svrhe, povrh analiza po facetama, SIPP-118 mogao koristiti i kao procjena generalnog funkcioniranja ličnosti u domeni selfa i odnosa s drugima.

Rezultati adaptacije kratke verzije upitnika PID-5 sugeriraju slabe psihometrijske karakteristike, iz čega proizlazi savjet da se ta verzija ne koristi. Iako je potvrđena očekivana petofaktorska struktura, skale se previše preklapaju, te postižu suviše visoke korelacije s upitnikom SIPP-118. Ovakva interpretacija se nipošto ne bi trebala generalizirati na duže verzije upitnika PID-5 od 220 (Krueger i sur., 2012) i 100 čestica (Maples i sur., 2015). Problem ove najkraće verzije upitnika može se dovesti u vezu s neadekvatnim odabirom čestica koje bi trebale predstavljati izrazito kompleksne dimenzije psihopatologije ličnosti u originalnoj verziji upitnika.

\section{Psihopatologija ličnosti i rizično ponašanje}

Prema alternativnom modelu poremećaja ličnosti DSM-5 stupanj funkcioniranja ličnosti prvi je kriterij koji je nužan za dijagnozu nekog od oblika poremećaja ličnosti. U drugom koraku regresijske analize (Tablica 6.) jasno se vidi kako su spekti selfa (kontrola emocija, stabilna slika o sebi i slično) nešto niži kod učenika s većim brojem rizičnih ponašanja. Nadalje, osobine ličnosti koje se koriste za postavljanje dijagnoze antisocijalnog poremećaja ličnosti pokazale su se važnima za predikciju rizičnog ponašanja. No, to se u većoj mjeri odnosi na rezultate dobivene upitnikom DiPOL nego PID-5. Prema DSM-5 antisocijalni poremećaj definira se izraženim dimenzijama antagonizma i dezinhibicije (naspram kompulzivnosti) (Asscher i sur., 2011; Strickland, Drislane, Lucy, Krueger i Patrick, 2013), što je u skladu s rezultatima dobivenim upitnikom DiPOL, dok se kod PID-5 samo skala dezinhibicije pokazala značajnim prediktorom.

Veći rezultati na skali antagonizma povezani su s većom vjerojatnošću da će doći do delinkventnih ponašanja (Muris i sur., 2013). Međutim, u odvojenim analizama, dvije vrste skala antagonizma rezultirale su različitim ishodom. Antagonizam mjeren DiPOL-om sadrži čestice koje se odnose na hostilnost, 
sumnjičavost prema drugima i impulzivnost. Izraženost ove osobine ličnosti osobu predisponira za rizična ponašanja iz razloga što utječe na percepciju i interpretaciju ponašanja drugih ljudi. Ovakve su osobe sumnjičave prema namjerama drugih ljudi, odnosno češće ih interpretiraju kao napad na sebe, a što onda može dovesti do obrambenog ponašanja, pa i eventualne želje za osvetom (Calvete, 2008). Također, važan aspekt antagonizma u sklopu DiPOL-a je i impulzivnost, zbog koje osobe ne analiziraju situacije iz različitih perspektiva i preispitivanje vlastitih pretpostavki, nego reagiraju odmah, na temelju afekta (Calvete, 2008). S druge, pak, strane, antagonizam mjeren kratkom verzijom PID-5 sadrži čestice koje se odnose na grandioznost (,С̌esto se moram nositi s ljudima koji su manje važni od mene."), traženje pozornosti (,,Volim privlačiti pažnju.") te makijavelizam (,,Ne predstavlja mi problem iskorištavati druge ljude."), stoga ne čudi razlika u rezultatima u odnosu na istoimenu skalu DiPOL.

U skladu s prethodnim istraživanjima (Asscher i sur., 2011; Krueger i Markon, 2014; Vitacco, Neumann, Robertson i Durrant, 2002), PID-ova dezinhibicija i DiPOL-ova kompulzivnost značajni su prediktori rizičnih oblika ponašanja. Za osobu koja je visoko na skali dezinhibicije karakteristično je impulzivno ponašanje, usmjerenost prema neposrednom zadovoljenju i nepromišljanje o posljedicama, dok niska kompulzivnost u okviru DiPOL-a predstavlja nedostatak savjesnosti, ambicioznosti i perfekcionizma. Rezultati ovog istraživanja upućuju na dvije odlike učenika s rizičnim ponašanjem, nedostatak samoregulacije i izostanak dugoročnog planiranja. Takvi pojedinci nisu skloni razmišljati o negativnim posljedicama rizičnog i delinkventnog ponašanja te će stoga biti skloniji ulasku u takva ponašanja (Jolliffe, 2013).

Pri interpretaciji ovih rezultata važno je uzeti u obzir da se prikupljeni podaci temelje na samoiskazima, što odražava način na koji se sudionici percipiraju i prezentiraju. U odnosu na klinički dijagnostički proces, u kojem se uz samoprocjene koriste i druge tehnike, moguće je da bi efekti ličnosti mogli biti drugačiji korištenjem drugačijih postupaka procjene (Hopwood i sur., 2011). Također, faktorsku strukturu SIPP-118 trebalo bi potvrditi konfirmatornom faktorskom analizom na novom uzorku.

Zaključno, osobine psihopatologije ličnosti i indeks funkcioniranja umjereno su povezani $\mathrm{s}$ rizičnim ponašanjem. Stupanj funkcioniranja ličnosti samostalno objašnjava $8.6 \%$, PID-5 oko $5 \%$, DiPOL oko $8 \%$, dok cjelokupni model objašnjava između 19 i $22 \%$ varijance SRDP-a. No, bez obzira na umjerenu povezanost ovo istraživanje dokazuje kako je alternativni model poremećaja ličnosti DSM-5 koristan dijagnostički okvir u sklopu kojega se mogu organizirati tretmani srednjoškolaca s problematičnim ponašanjem. Osim predviđanja rizičnog ponašanja, doprinos je ovog istraživanja i prilagodba upitnika SIPP-118 i PID-5 kratka forma za domaća istraživanja. Naime, prema našem saznanju ovi upitnici nisu prevedeni i do sada korišteni na hrvatskim ispitanicima. Originalna petofaktorska struktura upitnika SIPP-118 nije se potvrdila, što je u skladu i s prijašnjim istraživanjima. Međutim, 
upitnik sadrži velik broj faceta sa zadovoljavajućim koeficijentima pouzdanosti i mogao bi biti koristan u praktične svrhe, dok bi u istraživačke svrhe mogao biti koristan i kao mjera generalne procjene funkcioniranja ličnosti u domeni selfa i odnosa s drugima. Upitnik PID-5 pokazuje usporedive psihometrijske pokazatelje s verzijama upitnika na drugim govornim područjima. Međutim, problematičan su aspekt ovog upitnika visoke korelacije među skalama, što uvelike smanjuje prediktivnu valjanost upitnika. Problem kratke verzije upitnika jest i nedovoljna reprezentativnost sadržaja. Naime, originalni upitnik sadrži isti broj faceta kao što ova kratka verzija sadrži čestica. Stoga, većina faceta uopće nije zahvaćena ovom kratkom verzijom te se ne preporučuje koristiti. Za buduća se istraživanja savjetuje korištenje duže verzije upitnika PID-5, uz prethodnu adaptaciju na hrvatski jezik.

\section{Literatura}

Akaike, H. (1987). Factor analysis and AIC. Psychometrika, 52, 317-332.

American Psychiatric Association. (1994). Diagnostic and statistical manual of mental disorders (4th ed.). Washington, DC: American Psychiatric Association.

American Psychiatric Association. (2013). Online assessment measures: The Personality Inventory for DSM-5-Brief Form (PID-5-BF)-Child Age 11-17. Preuzeto s http://www.psychiatry.org/practice/dsm/dsm5/online-assessment-measures

Američka psihijatrijska udruga. (2014). Dijagnostički i statistički priručnik za duševne poremećaje, peto izdanje. Jastrebarsko: Naklada Slap.

Andrea, H., Verheul, R., Berghout, C. C., Dolan, C., Van der Kroft, P. J. A., Bateman, A. W., ... Busschbach, J. J. V. (2007). Measuring the core components of maladaptive personality: Severity Indices of Personality Problems (SIPP-118). Medical Psychology and Psychotherapy: Reports. Preuzeto s hdl.handle.net/1765/10066.

Arnevik, E., Wilberg, T., Monsen, J. T., Andrea, H. i Karterud, S. (2009). A cross-national validity study of the Severity Indices of Personality Problems (SIPP-118). Personality and Mental Health, 3, 41-55.

Asscher, J. J., van Vugt, E. S., Stams, G. J. J. M., Deković, M., Eichelsheim, V. I. i Yousfi, S. (2011). The relationship between juvenile psychopathic traits, delinquency and (violent) recidivism: A meta-analysis. Journal of Child Psychology and Psychiatry, 52, 11341143.

Bastiaansen, L., De Fruyt, F., Rossi, G., Schotte, C. i Hofmans, J. (2013). Personality disorder dysfunction versus traits: Structural versus conceptual issues. Personality Disorder: Theory, Research, and Treatment, 4, 293-303.

Bender, D. S., Morey, L. C. i Skodol, A. E. (2011). Toward a model for assessing level of personality functioning in DSM-5, part I: A review of theory and methods. Journal of Personality Assessment, 93, 332-346. 
Bentler, P. M. (2007). On tests and indices for evaluating structural models. Personality and Individual Differences, 42, 825-829.

Berghuis, H., Kamphuis, J. H. i Verheul, R. (2012). Core features of personality disorder: Differentiating general personality dysfunctioning from personality traits. Journal of Personality Disorders, 26, 704-716.

Browne, M. W. i Cudeck, R. (1993). Alternative ways of assessing model fit. U: K. A. Bollen i J. S. Long (Ur.), Testing structural equation models (str. 136-162). Beverly Hills, CA: Sage.

Calvete, E. (2008). Justification of violence and grandiosity schemas as predictors of antisocial behavior in adolescents. The Journal of Abnormal Child Psychology, 36, 1083-1095.

Clarkin, J. F. i Huprich, S. K. (2011). Do DSM-5 personality disorder proposals meet criteria for clinical utility? Journal of Personality Disorders, 25, 192-205.

Feenstra, D. J., Hutsebaut, J., Verheul, R. i Busschbach, J. J. V. (2011). Severity Indices of Personality Problems (SIPP-118) in adolescents: Reliability and validity. Psychological Assessment, 23, 646-655.

Fossati, A., Somma, A., Borroni, S., Markon, K. E. i Krueger, R. F. (2015). The Personality Inventory for DSM-5 Brief Form: Evidence for reliabilty and construct validity in a sample of community-dwelling Italian Adolescents. Assessment, 24, 615-631.

Gray, N. S. i Snowden, R. J. (2016). Psychopathy in women: Prediction of criminality and violence in UK and USA psychiatric patients resident in the community. Psychiatry Research, 237, 339-343.

Hopwood, C. J., Malone, J. C., Ansell, E. B., Sanislow, C. A., Grilo, C. M., Pinto, A., ... Morey, L. C. (2011). Personality assessment in DSM-5: Empirical support for rating severity, style, and traits. Journal of Personality Disorders, 25, 305-320.

Hopwood, C. J. i Sellbom, M. (2013). Implications of DSM-5 personality traits for forensic psychology. Psychological Injury and Law, 6(4), 314-323.

Hu, L. i Bentler, P. (1999). Cutoff criteria for fit indexes in covariance structure analysis: Conventional criteria versus new alternatives. Structural Equation Modeling, 6, 1-55.

Jolliffe, D. (2013). Exploring the relationship between the Five-Factor Model of personality, social factors and self-reported delinquency. Personality and Individual Differences, 55, 47-52.

Krueger, R. F., Derringer, J., Markon, K. E., Watson, D. i Skodol, A. E. (2012). Initial construction of a maladaptive personality trait model and inventory for DSM5. Psychological Medicine, 42, 1879-1890.

Krueger, R. F., Derringer, J., Markon, K. E., Watson, D. i Skodol, A. E. (2013). The Personality Inventory for DSM-5 Brief Form (PID-5-BF). Preuzeto s http://www.psychiatry.org/practice/dsm/dsm5/online-assessment-measures 
Krueger, R. F. i Markon, K. E. (2014). The role of DSM-5 personality trait model in moving toward a quantitative and empirically based approach to classifying personality and psychopatology. Annual Review of Clinical Psychology, 10, 477-501.

Krupić, D. i Ručević, S. (2015). Faktorska struktura i validacija upitnika Dimenzionalna procjena osobina ličnosti (DiPOL) za adolescente. Psihologijske teme, 24(3), 347-367.

Livesley, W. J. (2009). General assessment of personality disorder (GAPD). Toronto, Canada: Sigma Assessment Systems, Inc.

Loney, B. R., Taylor, J., Butler, M. A. i Iacono, W. G. (2007), Adolescent psychopathy features: 6-Year temporal stability and the prediction of externalizing symptoms during the transition to adulthood. Aggresive Behaviour, 33, 242-252.

Maples, J. L., Carter, N. T., Few, L. R., Crego, C., Gore, W. L., Samuel, D. B., ... Miller, J. D. (2015). Testing whether the DSM-5 Personality disorder trait model can be measured with a reduced set of items: An item response theory investigation of the Personality Inventory for DSM-5. Psychological Assessment, 27, 1195-1210.

Marsh, H. W. i Hocevar, D. (1985). Application of confirmatory factor analysis to the study of self-concept: First- and higher order factor models and their invariance across groups. Psychological Bulletin, 97, 562-582.

Morey, L. C. (2017). Development and initial evaluation of a self-report form of the DSM-5 level of Personality Functioning Scale. Psychological Assessment, 29, 1302-1308.

Morey, L. C., Berghuis, H., Bender, D. S., Verheul, R., Krueger, R. F. i Skodol, A. E. (2011). Toward a model for assessing level of personality functioning in DSM-5, part II: Empirical articulation of a core dimension of personality pathology. Journal of Personality Assessment, 93, 347-353.

Muris, P., Meesters, C. i Timmermans, A. (2013). Some youths have a gloomy side: Correlates of Dark Triad personality traits in non-clinical adolescents. Child Psychiatry and Human Development, 44, 658-665.

Quilty, L. C., Ayearst, L., Chmielewski, M. i Bagby, R. M. (2013). The psychometric properties of the Personality Inventory for DSM-5 in APA DSM-5 Field Trial Sample. Assessment, 20(10), 1-8.

Rossi, G., Debast, I. i van Alphen, S. P. J. (2016). Measuring personality functioning in older adults: Construct validity of the Severity Indices of Personality Functioning - Short Form (SIPP-SF). Aging and Mental Health, 20, 1-9.

Ručević, S. (2010). Psychopathic personality traits and delinquent and risky sexual behaviours in Croatian sample of non-referred boys and girls. Law and Human Behaviour, 34, 379-391.

Ručević, S., Ajduković, M. i Šincek, D. (2009). Razvoj upitnika samoiskaza rizičnog i delinkventnog ponašanja mladih (SRDP-2007). Kriminologija i socijalna integracija, 17(1), 1-11.

Stašević, I. i Derk, D. (2016). Osobitosti maloljetničke delinkvencije u Republici Hrvatskoj. Policija i sigurnost, 25(3), 259-275. 
Steiger, J. H. (2000). Point estimation, hypothesis testing, and interval estimation using the RMSEA: Some comments and a reply to Hayduk and Glaser. Structural Equation Modeling, 7(2), 149-162.

Strickland, C. M., Drislane, L. E., Lucy, M., Krueger, R. F. i Patrick, C. J. (2013). Characterizing psychopathy using DSM-5 personality traits. Assessment, 20(3), 327338.

Veltri, C. O. C., Sellbom, M., Graham, J. R., Ben-Porath, Y., Forbey, J. D. i White, R. S. (2014). Distinguishing Personality Psychopathy Five (PSY-5) characteristics associated with violent and nonviolent juvenile delinquency. Journal of Personality Assessment, 96(2), 158-165.

Verheul, R., Andrea, H., Berghout, C. C., Dolan, C., Busschbach, J. J. V., Van der Kroft, P. J. A., ... Fonagy, P. (2008). Severity Indices of Personality Problems (SIPP-118): Development, factor structure, reliability, and validity. Psychological Assessment, 20, 23-34.

Vitacco, M. J., Neumann, C. S., Robertson, A. A. i Durrant, S. L. (2002). Contributions of impulsivity and callousness in the assessment of adjudicated male adolescents: A prospective study. Journal of Personality Assessment, 78, 87-103.

Vrselja, I., Sučić, I. i Franc, R. (2009). Rizična i antisocijalna ponašanja mlađih adolescenata i privrženost školi. Društvena istraživanja, 18(4-5), 739-762.

Walsh, Z., Allen, L. C. i Kosson, D. S. (2007). Beyond social deviance: Substance use disorders and the dimensions of psychopathy. Journal of Personality Disorders, 21, 273-288.

Widiger, T. A. i Simonsen, E. (2005). Alternative dimensional models of personality disorder: Finding a common ground. Journal of Personality Disorders, 19(2), 110-130.

Wright, A. G. (2011). Qualitative and quantitative distinctions in personality disorder. Journal of Personality Assessment, 93, 370-379.

Zloković, J. i Vrcelj, S. (2010). Rizična ponašanja djece i mladih. Odgojne znanosti, 12(1), 197-213.

\title{
Validation of the Translation of SIPP-118 Questionnaire and the Short Version of PID-5
}

\begin{abstract}
Vast research indicates the importance of personality traits in predicting different types of risk behaviour in adolescents. In the last couple of years, several personality questionnaires have been successful in predicting risk behaviour in adolescents. The majority of these questionnaires have not been adapted in the Croatian language. The goal of this survey is to show Croatian translation of the Severity Indices of Personality Problems (SIPP-118) and the short version of the Personality Inventory for DSM-5 (PID-5). Dimensional Assessment of Personality Questionnaire (DAPQ) has been used to assess the convergent validity of PID-5 questionnaire, while Self-reported Delinquency and Risk Behaviours Questionnaire (SRDP) has been used for the assessment of the predictive
\end{abstract}


validity of PID-5 and SIPP-118. The survey was conducted on 497 high school and vocational students in Osijek, Beli Manastir, Đakovo and Donji Miholjac. The results of the confirmatory factor structure of SIPP-118 questionnaire did not confirm the anticipated factor structure. Five-factor structure PID-5 has been declared as the best model, but the scales are highly interrelated, which diminishes the divergent validity of the questionnaire. The results show that personality traits and personality functioning scales are moderately related to the tendency to risk and socially unacceptable behaviour. The hierarchical regression analysis has shown that a larger part of the variance in risk behaviour can be explained using DAPQ questionnaire than using PID-5. Considering the results of this survey, caution is advised in using translated questionnaires. PID-5

Keywords: risk behaviour, alternative model of personality disorders, adolescents, SIPP-118,

Primljeno: 28.3.2019. 